\title{
ANALISIS PENGARUH PEMBIAYAAN MUSYARAKAH TERHADAP PROFITABILITAS BANK SYARIAH DI INDONESIA
}

\author{
Elli Yani ${ }^{\mathrm{a}^{*}}$ Mukhlis M.Nur,LC,MA $\mathrm{a}^{\mathrm{a}^{*}}$ \\ ${ }^{a}$ Faculty of Economics and Business, Malikussaleh University \\ *Corresponding author: ellyoppo@gmail.com
}

Keywords: Musyarakah Financing, This study aims to determine and analyze the influence of musyarakah Profitability Of Islamic Bankks. financing on the profitability of islamic bankks in indonesia. This research uses secondary data in the form of financial statements on musyarakah financing for islamic bankks during 2008-2012, which are accessed on www.ojk.go.id. The data analysis method used is a simple linear regression with the help of eviews program. The partial result shows that the t-statistic value of musyarakah financial is 15,29370 with a probability of 0,0000 which means lower that the value of $\alpha=$ 0,05. It concludes that musyarakah Financiang has a significant effect on the profitability (ROA) of islamic bankks listed on the financial Services Authority (OJK) in 2008-2012.

\section{PENDAHULUAN}

Bank merupakan suatu lembaga yang menghimpun dana dari masyarakat dalam bentuk tabungan dan menyalurkan dana kepada masyarakat dalam bentuk kredit. Sistem perbankkan di Indonesia terbagi menjadi dua yaitu sistem perbankkan konvensional dan sistem perbankkan syariah. Perbedaan utama yang terdapat pada kedua jenis bankk ini adalah larangan riba (bunga) dalam perbankkan syariah.

Dunia perbankkan Indonesia telah menghadirkan perbankkan syariah yang sudah cukup lama ada. Namun beberapa tahun ini perkembangan perbankkan syariah cukup pesat. Terbukti dengan banyaknya bankk konvensional saat ini yang membuka unit usahanya dalam bentuk syariah seperti bankk syariah Mandiri, Bankk BTN Syariah dan banyak munculnya lembaga keuangan non bankk (LKNB) syariah seperti koperasi syariah,BMT, Asuransi Tafakkul, lembaga-lembaga zakat seperti LAZIS, BAZIS, dan Dompet Dhuafa (Huda dan Haykal, 2010).

Penelitian ini hanya memfokuskan pada produk musyarakah. Musyarakah secara bahasa berarti mencampur.

Profitabilitas adalah salah satu alat analisis yang digunakan untuk menilai kinerja manajemen dalam menghasilkan laba atau keuntungan dari operasi suatu usaha. Profitabilitas yang tinggi dapat menunjukkan kinerja keuangan yang baik.

Jadi, dalam penelitian ini mengambil objek di Bankk Umum Syariah periode tahun 2008 s.d 2012, berikut data laporan keuangan selama lima (5) tahun.
Tabel 1

Data Pendapatan Pembiayaan Musyarakah dan Profitabilitas

BankkUmum Syariah Periode Tahun 2008 s.d 2012

\begin{tabular}{|c|c|c|c|c|}
\hline No & Tahun & Bank & Musyarakah & Profitabilitas \\
\hline 1 & 2008 & \multirow{5}{*}{$\begin{array}{l}\text { PT. } \\
\text { Bankk } \\
\text { Aceh } \\
\text { Syariah }\end{array}$} & 7.411 & 29.787 \\
\hline 2 & 2009 & & 7.456 & 30.43 \\
\hline 3 & 2010 & & 8.42 & 39.42 \\
\hline 4 & 2011 & & 9.43 & 44.54 \\
\hline 5 & 2012 & & 10.412 & 54.562 \\
\hline 6 & 2008 & \multirow{5}{*}{$\begin{array}{l}\text { PT. } \\
\text { Bankk } \\
\text { Muamalat } \\
\text { Indonesia }\end{array}$} & 11.458 & 58.433 \\
\hline 7 & 2009 & & 12.987 & 61.642 \\
\hline 8 & 2010 & & 13.762 & 68.754 \\
\hline 9 & 2011 & & 14.624 & 70.243 \\
\hline 10 & 2012 & & 15.865 & 72.535 \\
\hline 11 & 2008 & \multirow{5}{*}{$\begin{array}{l}\text { PT. } \\
\text { Bankk } \\
\text { BRI } \\
\text { Syariah }\end{array}$} & 16.865 & 78.533 \\
\hline 12 & 2009 & & 17643 & 80234 \\
\hline 13 & 2010 & & 18.796 & 86.654 \\
\hline 14 & 2011 & & 19.775 & 89.947 \\
\hline 15 & 2012 & & 22.673 & 93.753 \\
\hline 16 & 2008 & \multirow{3}{*}{$\begin{array}{l}\text { PT. } \\
\text { Bankk } \\
\text { BNI } \\
\text { Syariah }\end{array}$} & 26.547 & 96.743 \\
\hline 17 & 2009 & & 39.634 & 154.482 \\
\hline 18 & 2010 & & 30.535 & 112.868 \\
\hline
\end{tabular}




\begin{tabular}{|c|c|c|c|c|}
\hline 19 & 2011 & & 36.744 & 154.423 \\
\hline 20 & 2012 & & 36.654 & 153.423 \\
\hline 21 & 2008 & \multirow{5}{*}{$\begin{array}{l}\text { PT. } \\
\text { Bankk } \\
\text { Syariah } \\
\text { Mandiri }\end{array}$} & 38.532 & 129.286 \\
\hline 22 & 2009 & & 42.432 & 132.535 \\
\hline 23 & 2010 & & 42.643 & 130.634 \\
\hline 24 & 2011 & & 47.786 & 136.543 \\
\hline 25 & 2012 & & 45.237 & 121.945 \\
\hline 26 & 2008 & \multirow{5}{*}{$\begin{array}{l}\text { PT. } \\
\text { Bankk } \\
\text { Mega } \\
\text { Syariah }\end{array}$} & 52.543 & 163.424 \\
\hline 27 & 2009 & & 57.345 & 164.576 \\
\hline 28 & 2010 & & 64.543 & 184.575 \\
\hline 29 & 2011 & & 62.975 & 153.769 \\
\hline 30 & 2012 & & 66.321 & 164.678 \\
\hline
\end{tabular}

Berdasarkan tabel di atas menunjukkan bahwa nilai ROA bervariatif mulai dari tahun 2008- 2012. Nilai ROA dan nilai profitabilitas saling mempengaruhi, artinya ada peningkatan profitabilitas dari tahun 2008 - 2012.

Berdasarkan permasalahan di atas maka penulis akan mengkaji permasalahan tersebut melalui penelitian dengan judul "Analisis Pengaruh Pembiayaan Musyarakah Terhadap Profitabilitas Bank Syariah Di Indonesia)".

Sisa kertas ini akan diisi oleh beberapa bagian: bagian kedua membahas kajian teoritis, bagian ketiga adalah metode penelitian dan data yang diadopsi dalam penelitian, bagian keempat membahas temuan dan implikasi penelitain bagian kelima memuat kesimpulan dan rekomendasi kebijakan.

\section{Kajian Teoritis}

\section{Pengertian Bank Syariah}

Merupakan lembagaa berbau syariah/bankk tanpa bunga. Bankk syariah ialah lembaga keuangan dimana sistem produknya sesuai dengan Al-Quran dan Hadits Nabi SAW. Arti Bankk itu sendiri merupakan lembaga perantara keuangan (financial intermediary) yang secara umum bergerak dibidang keuangan, menghimpun dana, menyalurkan dana atau kedua-duanya. Menurut (Muhammad, 2005) dalam bukunya Manajemen Bankk Syari'ah.

\section{Pembiayaan Musyarakah}

Menurut (Antonio, 2001), Al - Musyarakah adalah pejanjian antara 2 pihak atau lebih untuk melakukan suatu usaha/kegiatan tertentu dimana setiap pihak memberikan dana/amal dengan kesepakatan bahwa resiko dan keuntungan akan ditanggung kedua lela pihak. Istilah lain dari musyarakah adalah sharikah/ syirkah (kemitraan). Menurut (Yusuf dkk, 2010), musyarakah perjanjian para pemilik modal untuk kerjasama dengan tujuan mencari keuntungan.

Dengan demikian musyarakah merupakan kerja sama dalam suatu keegiatan usaha dengan menggunakan prinsip bagi hasil antara satu pihak dengan pihak yang lain sesuai dengan kesepakatan bersama.

\section{Pengertian Profitabilitas}

(Hanafi dan Halim, 2003) sebagai berikut:“ Profitabilitas adalah alat yang digunakan untuk mengetahui kemampuan suatu perusahaan untuk memperoleh laba (profitabilitas)".

Kesimpulannya, profitabilitas merupakan suatu alat/rasio yang melihat kemampuan perusahaan dalam menghasilkan laba untuk memastikan perusahan berjalan dengan baik. Kemampuan Profitabilitas atau Rentabilitas adalah suatu perusahaan dalam memperoleh laba akan dapat mengembangkan perusahaan tersebut.

\section{Kerangka konseptual}

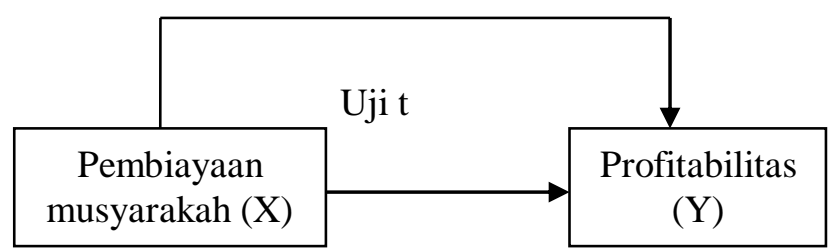

Gambar 1

kerangkaa konseptual

\section{Hipotesis}

Berdasarkan kerangka pemikiran, maka hipotesis penelitian ini dirumuskan sebagai berikut:

$\mathrm{Ha}$ : Pembiayaan musyarakah berpengaruh terhadap profitabilitas Bankk Umum Syariah di Indonesia.

Ho : Pembiayaan musyarakah tidak berpengaruh terhadap tingkat profitabilitas Bank Umum Syariah di Indonesia.

\section{METODE PENELITIAN}

Data dan Sumber Data

Penelitian ini menggunakan data sekunder yaitu data yang didapat dari lembaga tertentu atau instansi terkait di Bank Umum Syariah yang terdaftar di Otoritas OJK pada periode 20082012.

\section{Definisi operasional Variabel}

1. Pembiayaan Musyarakah adalah pejanjian antara 2 pihak atau lebih untuk melakukan suatu usaha/kegiatan tertentu dimana setiap pihak memberikan dana/amal dengan 
kesepakatan bahwa resiko sdan keuntungan akan ditanggung kedua lela pihak. Pembiayaan Musyarakah dalam penelitian ini diukur dalam satuan

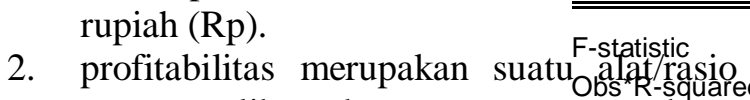
yang melihat kemampuan perusahaan dalam menghasilkan lab memastikan perusahan berjalan dengan baik. yang juga di ukur dala rupiah $(\mathrm{Rp})$

\section{Metode Analisis Data Uji Asumsi Klasik Uji Normalitas} untuk mengetahui apakah dalam model regresi panel variabel-variabelnya berdistribusi normal atau tidak.

\section{HASIL PENELITIAN DAN PEMBAHASAN}

\section{Hasil Uji Asumsi Klasik}

Hasil Uji Normalitas

Berdasarkan hasil uji Histogram-Normalit代-statistic
Tabel 2

Uji Heteroskedastisitas

Heteroskedasticity Test: Glejser

\begin{tabular}{lll} 
& 0.942625 & Prob. $F(1,36)$ \\
& 0.969605 & Prob. Chi-Square(1) \\
Scaled explained SS & 0.714039 & Prob. Chi-Square(1) \\
\hline
\end{tabular}

Dependent Variable: ARESID

Method: Least Squares

Date: 03/04/19 Time: 17:20

Sample: 20082012

Included observations: 30

$\begin{array}{llll}\text { Variable } & \text { Coefficient } & \text { Std. Error } & \text { t-Statistic }\end{array}$

\begin{tabular}{ll} 
& MUSYARAKAH \\
\hline \hline R-squared & \\
& Adjusted R-squared \\
& S.E. of regression \\
& Sum squared resid \\
& Log likelihood
\end{tabular}

sTest, terjadi atau tidaknya normalitas dapat sebagai pob(F-statistic)

berikut:

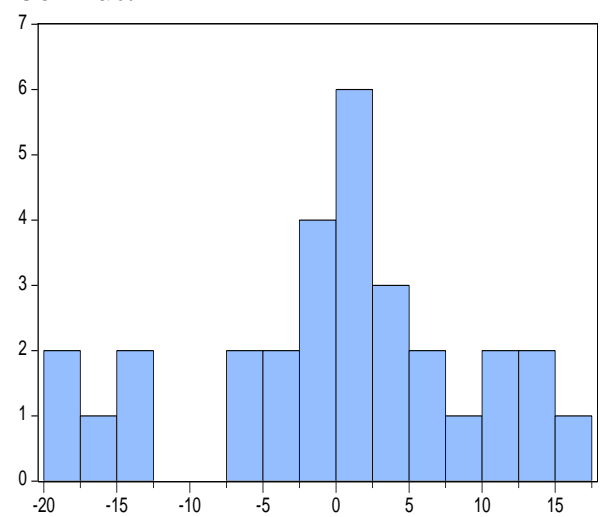

Sumber : Data di olah (2018)

Gambar 2

Histogram-hasil uji normalitas

Heteroskedasticity Test: Glejser

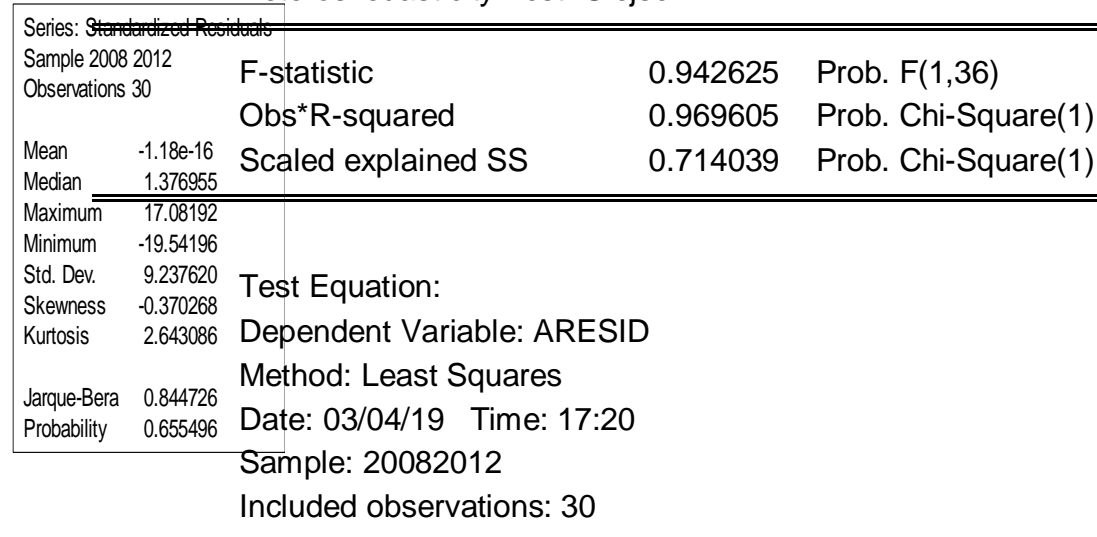

0.025516 Mean dependent var

-0.001553 S.D. dependent var

6.785207 Akaike info criterion

1657.405 Schwarz criterion

-125.6527 Hannan-Quinn criter.

0.942625 Durbin-Watson stat

0.338082

6.269271

$-0.970889$

Dari histogram diatas nilai Jarque Berra (JB) sebesar 0,844726, sementara nilai Chi Square dengan

Variable

Coefficient

Std. Error

t-Statistic

$\begin{array}{crrr}\text { C } & 12.22570 & 1.950099 & 6.269271 \\ \text { MUSYARAKAH } & -0.038886 & 0.040052 & -0.970889\end{array}$

melihat jumlah variabel independen (Pembiayaan squared

Musyarakah) sejumlah 1 variabel independen dengandjusted R-squared signifikansi 0,05 didapat nilai Chi Square sebesas. E. of regression 5,4572 yang berarti nilai JB < Chi Square $(0,844726$ Sum squared resid 5,4572). Sehingga penelitian ini berdistribusi normal. Log likelihood F-statistic Prob(F-statistic)
0.025516 Mean dependent var

-0.001553 S.D. dependent var

6.785207 Akaike info criterion

1657.405 Schwarz criterion

-125.6527 Hannan-Quinn criter.

0.942625 Durbin-Watson stat

0.338082

\section{Uji Heteroskedastisitas}

Untuk melihat terjadi atau tidaknya heteroskedasitas yaitu dengan melihat hasil regres seperti pada Tabel 4.4 sebagai berikut:

Sumber : Hasil Penelitian (data diolah), 2019

1. Hasil Analisis Regresi Linear Sederhana

Hasil regresi linier sederhana terhadap variabel-variabel penelitian menunjukkan hasilnya : 
Hasil Persamaan Regresi Linear Sederhana

Dependent Variable: $Y$

Method: Panel Least Squares

Date: 02/04/19 Time: 15:17

Sample: 20082012

Periods included: 5

Cross-sections included: 6

Total panel (balanced) observations: 30
Berdasarkan nilai thitung (t-statistic) pembiayaan musyarakah sebesar 15.29370 dengan probabilitas 0,0000 yang berarti < nilai $\alpha=$ 0,05.sehingga Pembiayaan Musyarakah berpengaruh signifikan terhadap Profitabilitas (ROA) BankkUmum Syariah di OJK yang terdaftar di OJK pada periode 2008-2012.

\begin{tabular}{|c|c|c|c|}
\hline Variable & Coefficient & Std. Error & t-StratistigarkanProhasil \\
\hline C & 34.55574 & 5.317417 & 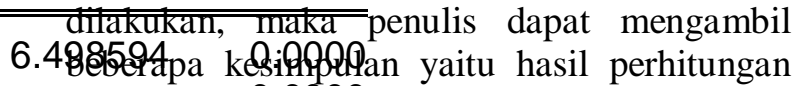 \\
\hline $\mathrm{X}$ & 2.312459 & 0.151203 & 15е9\&39arkan 0.099Pai \\
\hline R-squared & 0.893088 & Mean dependent var & 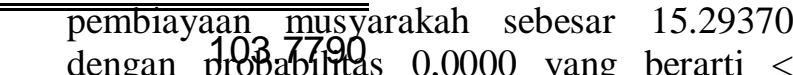 \\
\hline Adjusted R-squared & 0.889270 & S.D. dependent var & nilai $\alpha=45,03425$ hingga dapat disimpulkan \\
\hline S.E. of regression & 15.28517 & Akaike info criterion & bahwa P8m 355983 Musyarakah berpengaruh \\
\hline Sum squared resid & 6541.816 & Schwarz criterion & signifikan.44939. \\
\hline Log likelihood & -123.3397 & Hannan-Quinn criter. & BankkUnum 386 ah di OJK yang terdaftar di \\
\hline F-statistic & 233.8972 & Durbin-Watson stat & OJK pada periode $2008-2012$ \\
\hline Prob(F-statistic) & 0.000000 & & \\
\hline
\end{tabular}

Sumber: Hasil Penelitian, (Data diolah) 2019

Berdasarkan tabel 4.8 berikut persamaan regresi Persamaan Regresi (berdasarkan nilai koefisien OLS) yang terbentuk adalah:

Profitabilitas $(\mathrm{ROA})=34.55574+2.312459$

Musyarakah

Menurut tabel 4.8 nilai $\beta$ merupakan koefisien regresi untuk variabel X (Pembiayaan Musyarakah) memiliki slop positif, menunjukkan arah hubungan yang searah antara Pembiayaan Musyarakah dengan profitabilitas. Koefisien regresi Pembiayaan Musyarakah sebesar 2.312459 yang berarti apabila pembiayaan musyarakah meningkat sebesar $1 \%$ akan menyebabkan peningkatan profitabilitas (ROA) sebesar $2.312459 \%$.

\section{Pengujian Hipotesis}

\section{Uji Statistik}

Berdasarkan tabel 4.8, terlihat bahwa nilai thitung ( $t$-statistic) pembiayaan musyarakah sebesar 15.29370 dengan probabilitas 0,0000 yang berarti lebih $<$ nilai $\alpha=0,05$. Berarti bahwa Pembiayaan Musyarakah berpengaruh signifikan terhadap Profitabilitas (ROA).

\section{Uji Determinasi}

Analisis determinasi adalah ukuran yang menunjukkan seberapa besar variabel Pembiayaan Musyarakah memberikan kontribusi terhadap variable Profitabilitas (ROA).

Pembiayaan Musyarakah memiliki sumbangan pengaruh terhadap Profitabilitas (ROA) sebesar 0.889 atau $88 \%$ dan sisa dipengaruhi faktor lain sebesar $12 \%$ di BankkUmum Syariah di OJK pada periode 20082012.

\section{Pengaruh Pembiayaan Musyarakah terhadap Profitabilitas (ROA)}

\section{SARAN}

Berdasarkan keterbatasan dalam penelitian ini, maka saran untuk penelitianpenelitian selanjutnya:

1. Disarankan Pihak BankkUmum Syariah di OJK hendaknya meningkatkan pembiayaan Musyarakah. Hal ini disebabkan pembiayaan Musyarakah merupakan keunggulan BankkUmum Syariah di OJK yang mengedepankan prinsip kemitraan dan keadilan sehingga dapat memberikan manfaat lebih luas kepada sektor riil dan juga mempengaruhi pendapatan yang diterima BankkUmum Syariah di OJK selama ini.

2. Disarankan kepada Pemerintah supaya mengawasi kinerja BankkUmum Syariah di OJK agar mampu mengatur pembiayaannya dan dapat meningkatkan kinerja keuangan secara optimal. Pembiayaan Musyarakah membutuhkan pengawasan dan memiliki risiko yang lebih besar.

3. Disarankan kepada penelitian selanjutnya diharapkan menambahkan variabel terhadap penelitian yang akan dilakukan

\section{KEPUSTAKAAN}

1. Al-Jamal, Gharib. (2001). Al-Mashorif Wa Buyut at-Tamwiel al-Islamiyah, Dar al-Wathan, Riyadh, KSA.

2. Al Arif, M. Nur Rianto, (2012), Lembaga Keuangan Syariah, Suatu Kajian Teoritis Praktis, Pustaka Setia, Bandung.

3. Agnes Sawir, (2005). Analisis Kinerja Keuangan dan Perencanaan Keuangan. PT Gramedia Pustaka Utama, Jakarta. 
4. Ahmad Ath-Thoyaar, Abdullah bin Muhammad, (1414). Al-Bunuk AlIslamiyah Baina An-Nazhoriyah Wa At-Tathbiq, Dar al-Wathan, Riyadh, KSA.

5. Antonio, Muhammad Syafi'i. (2001). Bank Syariah dari Teori ke Praktek, Gema Insani, Jakarta.

6. A. Perwataatmadja, Karnaen, Antonio, Muhammad Syafi'i. (1992), Apa dan Bagaimana Bank Islam, Dana Bhakti Wakaf, Yogayakarta.

7. Ascarya. (2007). Akad dan Produk Bank Syariah. PT. RajaGrafindo Perkasa. Jakarta. s

8. Danupranata, Gita (2013), Buku Ajar Manajemen Perbankan Syariah, Salemba Empat, Jakarta.

9. Dahlan Siamat, (2005). Manajemen Lembaga Keuangan. Kebijakan Moneter dan Perbankan, Jakarta : Fakultas Ekonomi Universitas Indonesia, Edisi kesatu.

10. Eugene F, Brigham dan Houston F. Joel. (2006). Dasar-Dasar Manajemen Keuangan, alih bahasa Ali Akbar Yulianto, Buku satu, Edisi Sepuluh, PT. Salemba Empat, Jakarta.

11. Fahrul, Fauzan,. Arfan, Muhammad dan Darwanis. (2012). Pengaruh Tingkat Risiko Pembiayaan Musyarakah Dan Pembiayaan Murabahah Terhadap Tingkat Profitabilitas Bank Syariah (Studi Pada Bank Aceh Syariah Cabang Banda Aceh). Jurnal Akuntansi Fakultas Ekonomi Unsyiah.

12. Firdaus, Rachmat. (2001). Manajemen Dana Bank Syariah. Pustaka Media, Yogyakarta.

13. Ghozali, Imam. (2005). Aplikasi Analisis Multivariate dengan Program SPSS. Cetakan Keempat. Badan Penerbit Universitas Diponegoro, Semarang.
14. Huda Nurul, Mohamad Haikal. (2010). Lembaga Keuangan Islam Tinjauan Teoritis Dan Praktis. Prenada Media, Jakarta.

15. Halim, Abdul dan Hanafi, M. Mamduh. (2003). Akuntansi Manajemen, BPFE, Yogyakarta.

16. Hasibuan, Malayu. (2007). Dasar-Dasar Perbankan, Bumi Aksara, Jakarta.

17. Harahap, Sofyan Syafri. (2001). Teori Akuntansi, Raja Grafindo Persada, Jakarta.

18. Ikatan Akuntan Indonesia. (2009). Standar Akuntansi Keuangan. Jakarta: Salemba Empat.

19. Karim, Adiwarman Azwar. (2003). Bank Islam : Analisis Fiqih dan Keuangan, Edisi Pertama, IIIT Indonesia, Jakarta.

20. Kasmir. (2003). Bank Dan Lembaga Keuangan Lainnya. PT RajaGrafindo Persada, Jakarta.

21. (2004). Bank Dan Lembaga Keuangan Lainnya. PT RajaGrafindo Persada (Edisi Kedua), Jakarta.

22. Kusumawati, Shera Fuji. (2013). Pengaruh Risiko Pembiayaan Musyarakah Terhadap Profitabilitas (Studi Kasus Laporan Keuangan PT. Bank Muamalat Indonesia, Tbk Periode Tahun 2007-2012). Universitas Pendidikan Indonesia. (Tidak dipublikasikan).

23. Kuncoro, Mudrajad \& Suhardjono, (2006). Manajemen Perbankan : Teori dan Aplikasi. Edisi Kedua. BPFE, Yogyakarta.

24. Munawir, S. (2002). Akuntansi Keuangan dan Manajemen, Edisi Pertama, Penerbit BPFE, Yogyakarta.

25. Nazir, Muhammad. (2009). Metodologi Penelitian. Ghalia Indonesia, Bogor.

26. Muhammad. (2002). Manajemen Dana Bank Syariah. Ekonisia, Yogyakarta. 
27. (2005). Bank Syariah

Problema dan Prospek di Indonesia. Graha Ilmu, Yogyakarta.

28. Nursella dan Idroes, Ferry. (2011). Analisa Perbandingan Tingkat Risiko Pembiayaan Murabahah Dengan Risiko Pembiayaan Bagi Hasil Pada Perbankan Syariah, (Studi Kasus Unit Usaha Syariah Bank X) (periode 2010-2012). Jurnal Akuntansi.

29. Nurul Haq, (2001). Ekonomi Islam Hukum Bisnis Syariah, Teras, Yogyakarta.

30. Ridwan, Muhammad, (2011), Kontruksi Bank Syari'ah Indonesia. Pustaka SM, Yogyakarta.

31. Suhendi, Hendi. (2007). Fiqh Muamalah, Rajawali Press, Jakarta.

32. Sutojo, Siswanto. (2000). Menangani Kredit Bermasalah Konsep, Teknik dan Kasus, Damar Mulia Pustaka, Jakarta.

33. Sutedi, Adrian. (2009). Perbankan Syariah: Tinjauan dan Beberapa Segi Hukum. PT. Ghalia Indonesia, Jakarta.

34. Sugiyono. (2003). Metode Penelitian. Bandung: Alfabeta..

35. Undang-Undang Nomor 21 Tahun 2008 Tentang Perbankan Syari'ah.

36. Yusuf, Muhammad dkk. (2010). Bisnis Syariah. Mitra Wacana Media, Jakarta. 